\title{
The Scapegoat, Evangelical Revelation and Resentment
}

\author{
Stefano Tomelleri
}

\begin{abstract}
The mimetic desire that underlies resentment can enter into different and complex strategies of interaction. In his writings, Girard has indicated at least three such strategies: those of the solipsist, the non-conformist and the minimalist. His critical insight reveals indifference, transgression and minimalism to be strategies of resentment, where all of these are symptoms of an anthropological condition characterizing contemporary Western society today. At the same time, he sees evangelical revelation as the main source of our modern awareness of the mimetic nature of human beings: an awareness that has produced ongoing transformations in modernity linked to resentment. Moreover, he observes that it is the Judeo-Christian tradition itself that has disclosed the mimetic nature of human desire and the logic of resentment. Viewed from this perspective, modern humanity now has an extraordinary opportunity to renounce the scapegoating mechanism so as to resolve its resentments, as evangelical revelation makes reconciliation and social reconstruction possible.
\end{abstract}

KEYwords evangelical revelation; mimetic desire; modern society; resentment; scapegoat

\footnotetext{
\& Stefano Tomelleri, Department of Human and Social Sciences University of Bergamo, Dipartimento di Scienze umane e sociali Università di Bergamo, P. le S. Agostino, 24129 Bergamo, Italy ⿶stefano.tomelleri@unibg.it 
Mimetic Desire, Violence and the Scapegoating Mechanism

René Girard's work includes a link between desire, violence and the sacred. Throughout the history of mankind, the sacrifice of a victim (originally human and only subsequently animal) served an evolutionary function. The sacrifice prevented the spread of violent movements within archaic groups and human communities. According to Girard, one must recognize the crucial role played by the excluded (the submerged) in the construction of the society of survivors (the saved).

Girard follows the lessons of the major scholars of psychoanalysis and anthropology, performing a rigorous analysis of the mythical texts of Western Greek, African and Mesoamerican traditions. He listens in a refined and open manner to the message of the scriptures, of poets and of novelists (Shakespeare and Dostoevsky in particular), integrating the unbounded material of this human cultural repertoire within a single, dominant overall schema at whose center the religious experience acts as a kind of dynamic fulcrum. ${ }^{1}$

When it comes to religion, Girard considers only human nature, while many other scholars interested in similar disciplines often tend to reduce religion to a materialistic or socio-centric focus. The difference in Girard's method is that he makes the religious experience and society coincide. In short, the determining elements that make up this methodology are mimetic desire and the scapegoating mechanism.

In the history of mankind, the figure of the scapegoat, and more generally the sacrificial process, represent, for Girard, the starting point of civilization and the place where desire, violence and the sacred are conjoined. ${ }^{2}$

With the term "scapegoating mechanism," Girard indicates the starting point of civilization: the scapegoat is the sacrificial victim who attracts to and around himself or herself the violence of a community torn apart by the intensification of rivalry. Divided by competing desires, the community risks collapse without the corrective intervention of the scapegoat, ${ }^{3}$ who puts a halt

1. See Wolfgang Palaver, René Girard's Mimetic Theory, trans. Gabriel Borrud (East Lansing, MI: Michigan State University Press, 2013); Paul Ricoeur, "Religion and Symbolic Violence," Contagion 6, no. 1 (1999), doi:10.1353/ctn.1999.0003.

2. See Paul Dumouchel, "An Essay on Hominization: Current Theories, Girardian-Darwinian Approaches," in The Palgrave Handbook of Mimetic Theory and Religion (New York: Palgrave Macmillan, 2017); Pier Paolo Antonello and Paul Gifford, eds., Can We Survive Our Origins? Readings in René Girard's Theory of Violence and the Sacred (East Lansing, MI: Michigan State University Press, 2015); Pier Paolo Antonello and Paul Gifford, eds., How We Became Human. Mimetic Theory and the Science of Evolutionary Origins (East Lansing, MI: Michigan State University Press, 2015).

3. See René Girard, The Scapegoat, trans. Yvonne Freccero (Baltimore: Johns Hopkins University Press, 1986). 
to the self-destructive tendencies of the rivalry. Only the sacrifice of a common enemy allows rivals to feel themselves to be allied and united once again. The scapegoat experience is a regenerating event in religion and, as such, constitutive of the social order itself. The crisis of the community leads to a new, more rooted, authentic and socially shared membership. According to Girard, what distinguishes the expendable victim from the other members of the group is an essential quality: the victim's sacrifice cannot be avenged. The particular social relationship thanks to which perpetrating violence against someone exposes one to retaliation from others is absent. One aspect in common to all victims of a sacrifice is that their sacrifice is never avenged.

In archaic societies, human beings sought through myths and rites to prevent the destructive effects of vengeance. ${ }^{4}$ Through their ritual practices, they in every way tried to refine the prohibitions, attempting to consolidate the sacrificial order through myths. Ancient societies were, for a long period, trapped in a vicious circle of violence and the sacred: in response to the spread of reciprocal violence, their members unknowingly and automatically sought remedies through those sacred forms (myths, rites, sacrifices and prohibitions) which were in turn closely related to the legitimatizing power of violence. ${ }^{5}$

The originality of Girard's approach consists in his focus on religion as an originating and determining element of all social and cultural practices. The scapegoating mechanism is, for Girard, the creation of a "supernatural," "transcendental force of violent unanimity:"

If this victim can extend his benefits beyond death to those who have killed him, he must either be resuscitated or was not truly dead. The causality of the scapegoat is imposed with such force that even death cannot prevent it. In order not to renounce the victim's causality, he is brought back to life and immortalized, temporarily, and what we call the transcendent and supernatural are invented for the purpose. ${ }^{7}$

4. See Lucien Scubla, "Contribution à la théorie du sacrifice," in René Girard et le probleme du mal, ed. Michel Deguy and Jean-Pierre Dupuy (Paris: Édition Grasset and Fasquelle, 1982); Lucien Scubla, "Vindicatory System, Sacrificial System: from Opposition to Reconciliation," Stanford French Review 16, no. 1 (1992); Mark Anspach, Vengeance in Reverse. The Tangled Loops of Violence, Myth, and Madness (East Lansing, MI: Michigan State University Press, 2017).

5. See Paul Dumouchel, The Barren Sacrifice. An Essay on Political Violence (East Lansing, MI: Michigan State University Press, 2015).

6. René Girard, Violence and the Sacred, trans. Patrick Gregory (Baltimore: Johns Hopkins University Press, 1977), 87.

7. Girard, The Scapegoat, 44. 
Myths and rites express an attempt at containment, in the double meaning of curbing and co-opting the original violence. ${ }^{8}$ As he writes:

Unanimous victimage, in a sense, is only one mimetic phenomenon among others. At the time of Mensonge romantique ... this mimetic nature of victimage did not escape me, but its enormous potential in regard to primitive religion certainly did. When my attention turned to anthropology this potential finally dawned on me. I remember these days as the most exciting intellectual experience I ever had. The "essayistic" nature of La Violence et le sacré reflects that excitement too much and fails to convey as systematically and successfully as, I am sure, it can be conveyed, the massive evidence that designates unanimous victimage as the generative mechanism of all religious and cultural institutions. ${ }^{9}$

Hence, according to Girard, social order and peaceful coexistence amongst human beings are rooted in the victimary mechanism: every human society is built around its scapegoats, cyclically proposing ever more sophisticated forms of persecution and exclusion. ${ }^{10}$

For Girard, the source of rivalry and violence among human beings resides in mimetic desire or mimesis. This is an originary form of human desire. The human being is an incomplete being, always lacking something: therefore he or she is obliged to continually seek some achievement, some complementarity. The anthropogenesis par excellence is the act of desiring. Here, Girard borrows from some profound reflections within philosophy, in particular Alexandre Kojève's re-interpretation of Hegel's Phenomenology. Girard interprets desire in an anthropological sense: as a source of rivalry and conflict. For Kojève, the "desire for desire" determines the "recognition" of self-consciousness, the anthropogenic element par excellence. For Girard, such desire for desire recalls Hobbes' image of desire as a natural cause of war. In fact, Girard, like Hobbes, believed that when two desires imitate each other, they converge towards a single horizon. ${ }^{11}$ Their convergence generates conflict precisely for the sake of the satisfaction of the desires

8. Jean-Pierre Dupuy, Le sacrifice et l'envie (Paris: Calmann-Lévy, 1992).

9. René Girard, "Interview: René Girard," Diacritics 8, Special Issue on the Work of Rene Girard, no. 1 (1978): 31, doi:10.2307/464818.

10. See Jean-Pierre Dupuy and Paul Dumouchel, L'énfer des choses. René Girard et la logique de l'économie (Paris: Seuil, 1979); Stefano Tomelleri, Ressentiment. Reflection on Mimetic Desire and Society (East Lansing, MI: Michigan State University Press, 2015).

11. See Paul Dumouchel, "Hobbes: La Course à la Souveraineté," Stanford French Review 30, no. 1 (1986): 153-76. 
involved. It is this aspect of mimetic phenomena that leads to rivalry, violence and the scapegoat.

Girard's scapegoat-thesis can be compared to Emile Durkheim's anthropological theory of the sacred. The main similarity between the two positions on the origin of the first forms of social organization concerns the false transcendence of the sacred. The sacred is, for both, a lie everyone believes in. According to Durkheim, the "totem" is an illusory representation of society, while Girard views the "totem" as an illusory representation of the scapegoat. Nevertheless, unlike the French sociologist, Girard recognizes that the lie of the sacred has been exposed: the perverse intertwining of mimesis and the sacrificial process has been revealed by the evangelical message, which has laid bare the mimetic dynamics of the scapegoat.

In pre-Christian societies, the escalation of violence and vengeance was controlled by the sacred. However, Girard believes that after the Christian message appeared, those purifying and legitimizing forms gradually lost their sacred power. Modern man has witnessed a gradual loss in respect of the authorizing power of his sacrificial violence.

Girard's analysis in this theoretical domain is, moreover, similar to that of the German philosopher Friedrich Nietzsche. ${ }^{12}$ Both recognize the uniqueness of evangelical revelation and the insurmountable differences between the latter and the pagan religions. Both acknowledge that Christian anthropology has denounced the lie of the sacred, the violence of the heroes of the myths, and criticized the sacrificial immolation. However, unlike Nietzsche, Girard, as we shall see below, does not condemn Christian anthropology for having weakened humanity. He recognizes that this anthropology has also given us the possibility to reconcile without exclusion and without scapegoats. In short, evangelical revelation has unleashed an irreversible explosion of the sacred order of myths and rites.

Nevertheless, even more than its morality, this new and important anthropological opportunity does not eliminate the risk that human beings will still resort to violence. They are freed from the violence of the pagan sacred, but this freedom is not devoid of tragic implications. In late modernity, humanity has progressively lost any excuse that would serve to legitimize its violence, and this loss gradually renders legitimate violence inadequate as regards eliminating illegitimate violence and maintain social order. One of the consequences of this loss of the authorizing power of the sacrifice is the risk of an increasing exposure of social relations to mutual

12. See James G. Williams, "Nietzsche, Dionysus, and the Crucified," ed. James Alison and Wolfgang Palaver (London: Palgrave, 2018), 13-9. 
hatred-and, at the same time, as Girard warns us, to the chess game of rivalry and widespread resentment or ressentiment. ${ }^{13}$

\section{MODERn SECUlarization}

This interpretation of Western history in the light of evangelical revelation has a twofold significance for Girard: on the one hand, it bears witness to his in-depth research into religion, and on the other it expresses the results of an investigation that is rigorously theoretical.

The history of the West is, according to Girard, a manifestation of the karstic activity of evangelical revelation, whose basic idea is that the scriptures are at the origin of the process of secularization that characterizes the whole of modernity:

The true engine of progress is the slow decomposition of the closed worlds rooted in victim mechanisms. This is the force that destroyed archaic societies and henceforth the ones replacing them, the nations we call "modern" 14

As was previously stated, in pre-Christian societies the game of mimetic interference was controlled by the sacred: rites, initiation rituals and taboos. However, ever since the Christian message unveiled the close and vicious link between violence and the sacred order, the social structures have gradually lost their ability to contain the mimetic crises.

In the modern private world of the regenerative source of the scapegoat, a liberation of mimetic desire has taken place. Even so, according to Girard, unlike what much of contemporary common sense holds to be the case, the crisis of social structures signifies more than just a liberation from traditional memberships and an opening up to new horizons of freedom for our desires. Along with all this, secularization also entails the loss of the only authorizing principle of social reality: the fact is, through sacrifice, the mythical tale was able to control violence. Modern human beings, by contrast, finds themselves the only ones responsible for their actions and relationships, and behind the liberation of desire there hides a risk of a loss of differences and of the sense of hierarchy-something which often engenders deep resentment.

13. René Girard, "Foreword," in Ressentiment. Reflection on Mimetic Desire and Society (East Lansing, MI: Michigan State University Press, 2015), vii-xv.

14. René Girard, I See Satan Fall Like Lightning, trans. James G. Williams (Maryknoll, NY: Orbis Books, 2001), 166. 
For Girard, then, evangelical revelation marks a decisive metamorphosis in interactive dynamics, which entails a continuous reflective process. Modernity represents the continuation of a mimetic crisis without end, since catharsis through the scapegoat is no longer possible: in our age, desire is devoid of prohibitions. We want it to be unlimited, while humanity has learned that it can survive the acquisition of an object because objects are no longer sacred. Desire chooses increasingly more inaccessible objects: desire (almost) becomes a subject interested in self-preservation, one always caught in the trap of a self-defeating strategy. ${ }^{15}$

Paradoxically, as evidenced by the case of anorexia analyzed by Girard, ${ }^{16}$ only by irrevocably condemning oneself to defeat can desire avoid the painful and automatic transformation of every victory into frustration. Yet the difficult mimetic metamorphoses caused by evangelical revelation need not necessarily lead only to pain and suffering. According to him, thanks to the evangelical message, the modern age can learn to flourish and blossom again on a constantly renewed basis; it is increasingly capable of absorbing and assimilating internal rivalries. In the past, these were catastrophic for society, whereas now they are examples of innovation. Mimesis stimulates competition, and competition and rivalry can become a source of growth and progress.

Even so, the fact remains that the regenerative dynamics of modernity, in contrast to what those praising the "magnificent progressive fortunes" of neoliberal capitalism assert, does not leave the shadow of ancient violence behind. And we may add that after Christ, it is as if we were increasingly experiencing a spreading and delayed mimetic crisis in its final stage. ${ }^{17}$ From this perspective, modernity's fundamental idea of equality reveals its dual and ambivalent nature. The principles of equality and freedom are at the root of the birth of democracy and of civil and social rights. However, equality also entails differences, and the risk of exposing ourselves to relentless rivalries or the frustration of desires arising during the pursuit of ever more unattainable goals. We increasingly expect our neighbor to be equal to us, and any minimal difference, positive or negative, is seen as an injustice. For Girard, this profound ambivalence explains the resentment present in society today. ${ }^{18}$

15. See Jean Pierre Dupuy and Gunther Teubner, eds., Paradoxes of self-references in the humanities, law, and social sciences, Stanford Literature Review (Saratoga, Calif.: ANMA libri, 1990).

16. René Girard, Anorexia and Mimetic Desire (East Lansing, MI: Michigan State University Press, 2013).

17. Girard, I See Satan Fall Like Lightning.

18. Girard, "Foreword," in Ressentiment. Reflection on Mimetic Desire and Society. 
The Mimetic Figures of Resentment

It is here, in the maze of equality and free competition characterizing the relationships between individuals, that the mimetic form of resentment takes shape.

The term "resentment" does not refer to a psychological category, in the sense of something indicating a subjective reaction to humiliation or offense, but rather to an active mimetic disposition. The mimetic desire that underlies resentment can enter into different and complex strategies of interaction. In his writings, Girard has indicated at least three such strategies: ${ }^{19}$ those of the solipsist, the non-conformist and the minimalist.

In his essay entitled Camus's Stranger Retried, ${ }^{20}$ Girard studies the mimetic strategy of Meursault, the protagonist of Albert Camus's novel L'étranger. The latter is a solitary person who expresses a profound indifference towards other people, accusing society of a failure of understanding on the grounds that it does not accept his way of being-as someone indifferent and aloof. In reality, contemporary society has no grounds for objecting to people who behave like Meursault.

Girard shows that Meursault's solitude represents a strategy of resentment towards society because, although the solipsist is indifferent, they expect recognition from others, wanting the attention of others to satisfy their vanity. And this, in fact, is precisely the mimetic strategy of the solipsist. Girard shows that they are trapped in a contradiction: they do not want to be alone, but to be seen in society, while nevertheless choosing solitude. Their rejection of others, according to Girard, reveals the frustration of their real desire, which is to be desired by the other.

In the essay entitled Système du délire-à propos de l'anti-Oedipe, ${ }^{21}$ Girard analyzes the mimetic strategy of the non-conformist. Deleuze and Guattari's work L'anti-Oedipe played an important cultural role in the historical phase of 1968. The book was a huge success, hailing the "liberation of desire." Girard sees L'anti-Oedipe as perpetuating the old romantic and libertarian illusion of a necessarily good and peaceful desire. Desire would bring happiness, were it not hindered and repressed by the Judeo-Christian tradition. The rejection of the model, according to Girard, goes hand in hand with the creation of the rival/obstacle. The obsessive search for transgression is a natural way of prolonging desire. The denial of one's roots, the demand for

19. A first analysis of mimetic figures of resentment has been at the beginning in René Girard, Il risentimento, ed. Stefano Tomelleri (Milan: Raffaello Cortina, 1999).

20. René Girard, “Camus's Stranger Retried”, PMLA 79 (1964), doi:10.2307/461137.

21. René Girard, “Système du délire - à propos de L’anti-Oedipe”, Critique 28 (1972). 
total self-sufficiency, and nihilism, are, for Girard, all strategies of resentment directed towards everything that hinders desire. The others become just so many rivals who humiliate us, inducing in us a legitimate resentment.

Nevertheless, mimetic desire, in an extreme attempt to continue to desire, denying the model, can also lead to self-destruction, as in the desperate case of anorexia and bulimia nervosa, which represent an extreme stage of resentment and a minimalist culture of desire. In his book Anorexia and Mimetic Desire, ${ }^{22}$ Girard himself demonstrates that anorexia is a sophisticated form of renunciation and self-sacrifice, in contrast to the consumerist ostentation of the first inhabitants of modernity's nouveau riche. It is comparable to the potlatch rite of renunciation or showy consumption performed by some Native American tribes from the northwestern Pacific coast of the United States. The difference is that for the anorexic, the ritual process does not unfold in a tribal context, but rather in an individual and competitive one.

Anorexia is not solely a condition of discomfort for certain women. It is also an aesthetic, cultural trend of contemporary society. For Girard, we have before us a true culture of anorexia: in art, what triumphs is minimalism-the search for "increasingly less," with artists seeking consumption. Girard believes this culture to be inscribed in the social and cultural processes that have placed human beings' destiny in their own hands. The pursuit of self-fulfillment and autonomy, together with the affirmation of oneself at any cost, exacerbate the mimetic rivalry, which then becomes an end in itself: we prefer to eliminate ourselves than lose, and would rather die than accept the presence of the other.

\section{The IdeA of RESENTMENT From the NineteEnth}

to the Twentieth Century

Girard's critical insight reveals the strategies associated with resentment to be indifference, transgression and minimalism-all of which are symptoms of an anthropological condition characterizing contemporary Western society today. Moreover, his analysis shows that resentment is not the expression of a pathological way of acting, as described by Freud in Totem und Tabu.$^{23}$ To define pathological resentment is, after all, just to transform

22. Girard, Anorexia and Mimetic Desire.

23. Sigmund Freud, Totem und Tabu (Hamburg: Duncker and Humblot, 1912). 
certain types of person into new scapegoats. Resentment is a mimetic strategy that we experience in our complex and varied everyday life-an ambivalent normality.

In spite of this, the comparison with Freud is crucial for an in-depth investigation of the mimetic strategies of resentment. According to Freud, resentment is a classic case of the ambivalence of the human psyche. In the analysis of the taboo of the dead, Freud argues that the resentment of the dead toward the living hides our unconscious aggression toward the dead. The person that was loved was also hated, and now his or her vengeance is feared. The projection of aggression towards the other is transformed into the right of the dead to be resentful. This dynamic fulfills a crucial function in archaic societies: it constitutes the basis of the taboo. In modern civil society, the same dynamic produces the obsessions of the neurotic.

The Freudian analysis of resentment, like Girard's, demonstrates the continuity between the archaic world and modern civilization. Nevertheless, unlike Girard, Freud based his analysis on a dualistic vision of Eros and aggression, of the normal and the pathological. Meanwhile, in his re-interpretation of Freud, Girard shows that aggressiveness is of a piece with mimetic desire. Aggression certainly depends on the frustration of the libido, turning as it does against those who frustrate the latter-as Freud himself showed in the context of his initial psychoanalytic theory. However, aggression does not derive from frustration, but rather precedes it: both the satisfaction of Eros and of aggression, according to Freud, are sources of pleasure. Eros binds, unites and preserves, and thus satisfies through the preservation of its objects, whereas aggression is satisfied through the destruction of its ones. In Freudian theory, solidarity derives from Eros, while aggressiveness is, to a large extent-as per the norm-in negative objects, or what is channeled into transformative activities.

Girard's re-interpretation of Freudian psychoanalysis shows the libido to be mimetic desire: something that always unites, but which can also simultaneously destroy, the social bond. From the point of view of mimetic desire, aggressiveness exists in Eros, and vice-versa. Because desire is based on the other, it imitates what the other desires, tying those who desire to its model. However, beyond a certain threshold, what unites can be transformed into that which destroys any social relationship. What we desire mimetically-success, power, victory-is also what makes us rivals in respect of the fulfillment of our desires. It should be added that the risk of a dualistic vision of the normal and the pathological, of interiority and society, of a type of human being who is resentful and another who is healthy, is, according to Girard, one that many scholars face when analyzing resentment. 
The French scholar refers to Nietzsche's analysis of the idea of resentment. According to Girard, even Nietzsche (when describing the morality of the slaves) thinks of resentment as an emotion typical of modernity. Resentment is the specific "underground" (in the Dostoevskyan sense) modality of the revolt of the slaves. It is experienced by those who, instead of affirming themselves, reject all that is superior to them, acting on the basis of externally imposed forms of negative conditioning (the unjust "superiority" of the other). Resentment belongs only to the "slaves," who envy the rich and the powerful. The slave is someone who is not capable of being autonomous and active.

On Nietzsche's account, this revolt of the slaves began with the people of Israel, who were always trapped within their history as victims and unable to take revenge on their persecutors, toward whom they harbored grudges and feelings of hatred. Nietzsche believes that Christian love is the realization of this deep-seated resentment. For him, then, we feel resentment because we are mediocre people-slaves of the other, on whom we depend. Our lack of emancipation from others causes frustration and discomfort, while wisdom can only come from our being independent of them. However, according to Girard, this analysis paradoxically condemns Nietzsche himself to a state of resentment. ${ }^{24}$ With every attempt to free himself from his models, Nietzsche found himself clashing with the latter as he encountered their inevitable resistance as rivals. ${ }^{25}$

So, in the end, should we not ask ourselves why it is that we feel troubled by our neighbor to the point of despising them, and wishing to get rid of them? If, in order to be happy, our neighbor must be extraneous to our destiny, why do we continue to seek their approval? These are the questions Max Scheler also poses, in Ressentiment. ${ }^{26}$ Scheler senses that resentment arises from the desire to provide oneself with a model: humans have a propensity to compare themselves to others, from which they learn that the other has something that they want, too. Failing in the attempt at appropriation produces a feeling of impotence, which gives rise to resentment. Scheler once again stresses the characteristic of reaction and emotional backlash. Unlike Girard, though, he does not grasp the fact that desire without an object entails the inevitable presence of both admiration and

24. René Girard, "Nietzsche and Contradiction," Stanford Italian Review 6 (1986).

25. René Girard, "The Founding Murder in the Philosophy of Nietzsche," in Violence and Truth: On the Work of René Girard, ed. Paul Dumouchel (Stanford: Stanford University Press, 1988), 231-46.

26. Max Scheler, Ressentiment, trans. William Holdheim, ed. Lewis A. Coser (New York: Schocken, 1972). 
hatred for the other: the latter is both a model and an obstacle, a source of inspiration and frustration.

\section{A New Perspective on Evangelical Revelation}

The mimetic strategies associated with resentment bring to light the incompleteness of every human actor, along with their relational nature: even our innermost affective experience refers to the actions of others. We have already seen the importance of mutual comparisons, of our continual and incessant exchanging of glances. Human beings just are mimetic creatures.

Girard sees evangelical revelation as the main source of our modern awareness of the mimetic nature of human beings: an awareness that has produced ongoing transformations in modernity linked to resentment. He observes that the Judeo-Christian tradition has itself disclosed the mimetic nature of human desire, as well as the logic of this resentment:

One essential thing about ressentiment is that its ultimate target is always ressentiment itself, its own mirror image, under a slightly different mask that makes it unrecognizable. Ressentiment is the interiorization of weakened vengeance. Nietzsche suffers so much from it that he mistakes it for the original and primary form of vengeance. He sees ressentiment not merely as the child of Christianity, which it certainly is, but also as its father, which it certainly is not. Ressentiment flourishes in a world where real vengeance (Dionysus) has been weakened. The Bible and the Gospels have diminished the violence of vengeance and turned it to ressentiment not because they originate in the latter but because their real target is vengeance in all its forms, and they have only succeeded in wounding vengeance, not in eliminating it. The gospels are indirectly responsible; we alone are directly responsible. Ressentiment is the manner in which the spirit of vengeance survives the impact of Christianity and turns the gospels to its own use. ${ }^{27}$

Viewed from this perspective, modern humanity has an extraordinary opportunity to renounce the scapegoating mechanism for the sake of resolving its resentments, in that evangelical revelation makes reconciliation and social reconstruction possible. ${ }^{28}$ The universe of knowledge of human beings

27. See René Girard, "Dionysus versus the Crucified," Modern Language Notes 92 (1977): 825, doi:10.2307/2906812.

28. See Bernardino Fantini, Dolores Martín Moruno, and Javier Moscoso, eds., On Resentment: Past and Present (Cambridge: Cambridge Scholars Publishing, 2013). 
disclosed by evangelical revelation recognizes that each of our affective experiences is profoundly ambivalent, attributing to each one, resentment included, equal citizenship. ${ }^{29}$

Accepting the human being's profound need to achieve self-fulfillment through the other can prove a valuable aid in learning to love even our own modern institutions, such as democracy, human rights and justice. This need not mean withdrawing the hidden gaze of mimetic desire, which Nietzsche, better than anyone else, shed light on, because those "basements" cannot be separated from the dignity of our weaknesses, of our fragility-in a word, from the dignity of our humanity.

Resentment, from a mimetic point of view, is not ascribable to any intrapsychic category-be it that of vital strength, weakness, incapacity for self-affirmation, or an index of subjective reaction to humiliating experiences. Rather, it is an active construct built up socially over the course of interactions with others. Resentment and violence take shape in the very heart of human rivalry, in an anthropological condition of reciprocal interdependence.

Resentment eventually arises when we sense we have missed an opportunity: when we sense that we are unable, and do not know how, to establish a positive bond with others. It is not just some evil, or an emotion with negative value. It may be the engine of change, but it requires that we act in a constructive and socially conscious manner. At the same time, the experience of powerlessness that is typical of resentment can be transformed into a search for solidarity and fraternity: the suffering of resentment becomes a necessary step on the way to fully realizing that the comparison with the other is not only a source of humiliation, of rivalry, but also a space of solidarity and mutual interdependence. The desire to respond to violence thus becomes a desire to restore solidarity, while resentment, which is itself part of that response, instead of poisoning the soul becomes the soul's salvation.

René Girard sees the founding principles of this orientation in evangelical revelation. For Girard, the Gospels contains a new perspective that allows for reconciliation without becoming trapped in the mimetic strategies of resentment:

The Passion reveals ... mimetism and the only way out of it ... We are not headed towards reconciliation in any necessary way, but the idea that men have no other saving recourse to be reconciled is indeed the complementary 
face of the escalation to extremes. This truth points to the founding murder-and draws its sting. ${ }^{30}$

The fundamental aspect of this new perspective contained in the Gospels is a full acceptance of responsibility for the future society we intend to construct. Deprived of archaic sacrificial protection against our own self-generated violence, we stand, as never before, at risk of an explosion of the latter. The evangelical message expresses the awareness that violence is a lie, and evil only something chosen by human beings themselves.

Much work still needs to be done in this regard, as we are only at the beginning of this search for the roots of a possible "theory of humanity" and of the type of society contained in evangelical revelation. ${ }^{31}$ This theory reveals the antagonisms of human relationships while at the same time illuminating the capacity of the individual or the community to survive, the possibility of recreating the social bond, and the search for corrective measures to end conflicts without the need to produce scapegoats.

The nature and future of modernity are undermined from within by evangelical revelation, in that such knowledge concerning mimetic processes renders ineffective all of the devices humanity has invented to fight violence. Modernity, according to Girard, makes the ethical and religious choice between love and violence increasingly stark.

To make this choice, we must begin by accepting the fragility of the human condition. Resentment does not just condemn us to failure. In this sense, Nietzsche was too harsh, even with himself. The human condition, with all its miseries, also holds out the possibility of love: through suffering and rejoicing, feeling emotions, we are bound to each other in a common destiny. It is necessary to accept the truth that the human being is fulfilled through the other. This is an obligatory first step if, in arduous pursuit of a peaceful existence, we are to emerge from the vicious circle of resentment.

When the figure of Christ bore witness to the innocence of the scapegoat, the illusory belief that violence could be expelled by violence was revealed as such. However, a way to ensure peace amongst human beings was also disclosed. For this peace is only possible through love for, and a radical acceptance of, the other.

30. René Girard, Battling to the End: Conversation with Benoît Chantre (East Lansing, MI: Michigan State University Press, 2010), 101.

31. See René Girard, Things Hidden Since the Foundation of the World, trans. Stephen Bann and Michael Metteer (Stanford: Stanford University Press, 1987). 


\section{BIBLIOGRAPHY}

Anspach, Mark. Vengeance in Reverse. The Tangled Loops of Violence, Myth, and Madness. East Lansing, MI: Michigan State University Press, 2017.

Antonello, Pier Paolo, and Paul Gifford, eds. Can We Survive Our Origins? Readings in René Girard's Theory of Violence and the Sacred. East Lansing, MI: Michigan State University Press, 2015.

- , eds. How We Became Human. Mimetic Theory and the Science of Evolutionary Origins. East Lansing, MI: Michigan State University Press, 2015.

Dumouchel, Paul. The Barren Sacrifice. An Essay on Political Violence. East Lansing, MI: Michigan State University Press, 2015.

- . "An Essay on Hominization: Current Theories, Girardian-Darwinian Approaches." In The Palgrave Handbook of Mimetic Theory and Religion, 13-19. New York: Palgrave Macmillan, 2017.

— . "Hobbes: La Course À La Souveraineté." Stanford French Review 30, no. 1 (1986): 153-76.

Dupuy, Jean-Pierre. Le Sacrifice et L'envie. Paris: Calmann-Lévy, 1992.

Dupuy, Jean-Pierre, and Paul Dumouchel. L'énfer Des Choses. René Girard Et La Logique De L'économie. Paris: Seuil, 1979.

Dupuy, Jean Pierre, and Gunther Teubner, eds. Paradoxes of Self-References in the Humanities, Law, and Social Sciences, Stanford Literature Review. Saratoga, Calif.: ANMA libri, 1990.

Fantini, Bernardino, Dolores Martín Moruno, and Javier Moscoso, eds. On Resentment: Past and Present. Cambridge: Cambridge Scholars Publishing, 2013.

Freud, Sigmund. Totem Und Tabu. Hamburg: Duncker and Humblot, 1912.

Girard, René. Anorexia and Mimetic Desire. East Lansing, MI: Michigan State University Press, 2013.

- Battling to the End: Conversation with BenoîT Chantre. East Lansing, MI: Michigan State University Press, 2010.

— . "Camus's Stranger Retried." PMLA 79 (1964): 519-33. doi:10.2307/461137.

— . "Dionysus Versus the Crucified." Modern Language Notes 92 (1977): 816-35. doi:10.2307/2906812.

— . "Foreword." In Ressentiment. Reflection on Mimetic Desire and Society. East Lansing, MI: Michigan State University Press, 2015.

- . "The Founding Murder in the Philosophy of Nietzsche." In Violence and Truth: On the Work of René Girard, edited by Paul Dumouchel, 231-46. Stanford: Stanford University Press, 1988.

- . I See Satan Fall Like Lightning. Translated by James G. Williams. Maryknoll, NY: Orbis Books, 2001.

- Il Risentimento. Edited by Stefano Tomelleri. Milan: Raffaello Cortina, 1999.

— . "Interview: René Girard." Diacritics 8, Special Issue on the Work of Rene Girard, no. 1 (1978): 31-54. doi:10.2307/464818.

— . "Nietzsche and Contradiction." Stanford Italian Review 6 (1986): 53-65.

- The Scapegoat. Translated by Yvonne Freccero. Baltimore: Johns Hopkins University Press, 1986.

— . "Système du délire - à propos de L'anti-Oedipe." Critique 28 (1972): 716-28.

- Things Hidden since the Foundation of the World. Translated by Stephen Bann and Michael Metteer. Stanford, CA: Stanford University Press, 1987.

- . Violence and the Sacred. Translated by Patrick Gregory. Baltimore: Johns Hopkins University Press, 1977. 
Palaver, Wolfgang. René Girard's Mimetic Theory. Translated by Gabriel Borrud. East Lansing, MI: Michigan State University Press, 2013.

Ricoeur, Paul. "Religion and Symbolic Violence." Contagion 6, no. 1 (1999): 1-11. doi:10.1353/ ctn.1999.0003.

Scheler, Max. Ressentiment. Translated by William Holdheim. Edited by Lewis A. Coser. New York: Schocken, 1972.

Scubla, Lucien. "Contribution À La Théorie Du Sacrifice." In René Girard Et Le Probleme $\mathrm{Du} \mathrm{Mal}$, edited by Michel Deguy and Jean-Pierre Dupuy, 103-68. Paris: Édition Grasset and Fasquelle, 1982.

— . "Vindicatory System, Sacrificial System: From Opposition to Reconciliation." Stanford French Review 16, no. 1 (1992): 55-76.

Tomelleri, Stefano. Ressentiment. Reflection on Mimetic Desire and Society. East Lansing, MI: Michigan State University Press, 2015.

Williams, James G. "Nietzsche, Dionysus, and the Crucified." Edited by James Alison and Wolfgang Palaver, 159-65. London: Palgrave, 2018. 